\title{
VOJNA MOĆ VODEĆIH SVETSKIH ZEMALJA I DEFICIT RESURSA
}

\author{
Hatidža Beriša \\ Univerzitet odbrane u Beogradu, Vojna akademija \\ Mile Rakić \\ Institut za političke studije, Beograd
}

Kontinuirano snabdevanje resursima utiče na ekonomsku stabilnost zemlje, usklađivanje njene privredne strukture i obezbeđivanje planirane dinamike privrednog rasta, što se, u suštini, odražava i na njenu odbrambenu sposobnost. Zemljama koje imaju bogate resurse (posebno rezerve nafte) to bi trebalo da bude dobra osnova ekonomske i političke stabilnosti, kao i činilac vojnog jačanja. Da bi se predupredila moguća iznenađenja oko snabdevanja resursima, mnoge zemlje, posebno najrazvijenije, odnosno njihove vojno-političke organizacije, preduzimaju najrazličitije mere, uključujući i vojne intervencije u određenim zemljama, ukoliko se proceni da postoji opasnost da se poremete cene resursa na tržištu. Upravo zbog toga, područja bogata ležištima resursa bila su, po pravilu, izvor kriza. Polazna stanovišta ovog rada su: globalno liderstvo SAD, ubrzani rast vojne moći Kine, narastajući prostor za restauraciju vojne moći Ruske Federacije, EU kao globalni konkurent SAD.

Ključne reči: vojna moć, resursi, deficiti, velike sile, Rusija, $S A D, N R$ Kina, EU

\section{Uvod}

Moć u najopštijem smislu predstavlja sposobnost ostvarivanja željenih ciljeva i uticanje na promene u ponašanju drugih kako bi se ti ciljevi dostigli. Sposobnost ostvarivanja željenih ishoda povezuje se sa elementima ekonomske, političke, vojne i kulturno-ideološke nadmoći, odnosno sa posedovanjem određenih resursa, pre svega stanovništva, teritorije, prirodnih resursa, privredne snage, vojne sile i političke stabilnosti. ${ }^{1}$ Tradicionalno, moć se vezivala za vojnu moć, a test velike moći bila je „snaga za rat”. Otuda moć vojne sile predstavlja osnovu takozvane tvrde moći, pri čemu njen značajni aspekt predstavlja i ekonomska moć. Vojna i ekonomska moć, kao primeri tvrde moći, imaju za cilj navođenje drugih da promene svoj stav, odnosno tvrda moć počiva na podsticajima ili pretnjama. ${ }^{2}$ Danas su se temelji moći pomerili od težišta na vojnu moć i osvajanja, a jedan od razloga, paradoksalno, jeste nuklearno oružje. Brojni, pre svega zapadni teoretičari smatraju da u uslovima globalnog svetskog društva relevantnost vojne moći opada na račun ekonomske moći kao istinske. Tako Naj misli da se „uloga vojne sile

\footnotetext{
${ }^{1}$ Džozef S. Naj, Paradoks američke moći, BMG Beograd 2004, str. 23.

${ }^{2}$ S. Sojanović i S. Nikolić, „Nova globalna podela moći”, Beograd, 2009, str. 2.
} 
suptilno menja u korist ekonomske vitalnosti, tehnološke moći, naročito komunikacija”, kao i „diplomatske veštine i privlačnosti kulturnih vrednosti”. Ekonomska moć postala je značajnija nego ranije zbog relativnog porasta troškova sile i zbog toga što ekonomski ciljevi imaju veliku vrednost u postindustrijskim društvima. Međutim, postoji i indirektan način za vršenje moći. Određena država može dostići željene rezultate u svetskoj politici time što će druge zemlje želeti da je slede, prihvatajući njene vrednosti, težeći njenom nivou prosperiteta i otvorenosti. Ovaj aspekt moći - privoleti druge da rade ono što želite čini suštinu meke moći. Ako mogu da te privolim da želiš da radiš ono što ja hoću, onda ne moram da te primoravam da radiš ono što ne želišs. ${ }^{3}$

Meka moć povezana je sa neopipljivim resursima moći kao što su privlačna kultura, ideologija i institucije. Ona nije isto što i uticaj, mada je jedan od izvora uticaja. Takođe, više je od ubeđivanja ili sposobnosti pokretanja ljudi argumentima. To je sposobnost zavođenja i privlačenja, a privlačnost često vodi pristanku ili podržavanju. Meka moć danas predstavlja značajnu realnost. ${ }^{4}$

Naravno, tvrda i meka moć su povezane i mogu osnaživati jedna drugu. Obe su aspekti sposobnosti ostvarivanja ciljeva uticanjem na ponašanje drugih. Ponekad isti resursi moći mogu uticati na ceo spektar ponašanja, od prinude do privlačenja. Zemlja čija je ekonomska i vojna moć u opadanju verovatno će izgubiti svoju sposobnost da oblikuje međunarodnu politiku, kao i svoju privlačnost. $^{5}$

\section{Globalno liderstvo SAD}

Nestanak velikog vojnog, političkog i ekonomskog rivaliteta supersila, koji je bio aktuelan tokom većeg dela druge polovine 20. veka, trebalo je da bude kraj dominacije sile. Međutim, očekivanja da će završetkom hladnog rata i sve snažnijim ekonomskim povezivanjem savremenog sveta uloga vojne sile biti marginalizovana, pokazala su se kao preuranjena. Isto tako, verovanje da će nakon raspada Varšavskog bloka na političkoj sceni sveta svoju misiju okončati i NATO, kao elemenat blokovskog modela organizovanja međunarodnog poretka, pokazalo se nerealnim. Nakon izvesnog zastoja u procesu jačanja vojno-tehničkih potencijala širom sveta, u poslednjoj deceniji 20. veka ponovo je intenziviran proces naoružavanja, a militarizam, kao svojevrsni društveni fenomen, postaje imanentan odraz politike najmoćnijih država, pre svega Sjedinjenih Američkih Država.

Globalizacija međunarodnih odnosa i sve jače uzajamne veze između društava i naroda nametnuli su potrebu za novim konceptom bezbednosnog organizovanja. Okosnicu novog redefinisanog koncepta globalne bezbednosti čini sve veća internacionalizacija bezbednosti, njena deteritorijalizacija i neprekidno nastojanje da se globalizuje vojna moć i uspostavi efikasan kolektivni sistem bezbednosti. U takvim, suštinski izmenjenim uslovima, smatra Smilja Avramov, bezbednost se konstruiše na globalnom nivou i prevodi u ne vojnu sferu, tj. u ekonomsku sferu i sferu ljudskih prava. Pokazalo se, isto tako, da se pod novim modelom bezbednosnog organizovanja podrazumeva, pre svega, moć vojne sile, koja je, bar kad je reč o evroatlantskoj bezbednosnoj zajednici, sve manje u nadležnosti nacionalne države i zadobija anacionalan ka-

\footnotetext{
${ }^{3}$ Džozef S. Naj, isto, str. 3.

${ }^{4}$ Džozef S. Naj, isto, str. 300.

${ }^{5}$ Isto, str. 30 .
} 
rakter. U prilog takvoj oceni govori i činjenica da je reformisani NATO, s redefinisanom misijom, nastavio da traje dobijajući još dominantniju ulogu u kreiranju struktura bezbednosnog organizovanja velikog dela sveta. Ambicije vezane za širenje tog saveza, u kojem je neprikosnovena pozicija SAD, kao njegovog ključnog kreatora, kao i sve prepoznatljivija nastojanja EU da jača svoj bezbednosni i odbrambeni identitet, ukazuju na tendenciju jačanja globalne vojne sile. Takve tendencije potvrđuju predviđanja da će razlozi moći i dalje imati najveću važnost u delovanju ključnih transnacionalnih subjekata međunarodne politike i da se odražavaju na jačanje militarističkog pristupa međunarodnim odnosima, čime se znatno pojačavaju neizvesnost i nestabilnost svetskog poretka. Procenjuje se da će SAD i dalje biti najveća sila u svetskoj zajednici, jer njen globalni ekonomski, tehnološki, vojni i politički uticaj neće imati premca ni među državama ni među regionima i međunarodnim organizacijama u prvim decenijama 21. veka. Sjedinjene Države će ostati dominantna vojna sila, s odlučujućim vođstvom u oblasti informacione tehnologije i tehnologije oružja. Ta moć ne samo da će osigurati njihovo prvenstvo, nego će im omogućiti i da budu ključni pokretački faktor u međunarodnom sistemu i nastojanju da se stvori trajni politički poredak od kojeg ne preti opasnost. Takva pozicija omogućava SAD da budu „odlučujući akter u bilo kom sukobu, u bilo kom delu sveta”, i da se nametnu kao garant globalne bezbednosti. ${ }^{6}$ Isto tako, nema sumnje da će se SAD i dalje smatrati vodećim promoterom i zaštitnikom globalizacije. Nastojanja američke globalne politike da svet u celini uređuje na hegemonističkim pozicijama veoma ubedljivo iskazuje Madlen Olbrajt: „Amerikanci moraju da budu mnogo više od publike, više od aktera; mi moramo da budemo autori istorije našeg doba."7 Hegemonistički položaj SAD i na njemu zasnovana mogućnost da oblikuju svet, u središte neminovno dovode sve veću ulogu vojne sile i tendenciju ka njenoj globalizaciji. U vojnoj moći SAD su jedina država koja ima i nuklearno oružje i konvencionalne snage sa globalnim dosegom i predvodnik su revolucije u vojnim pitanjima koja se zasniva na informacijama. Poznato je, na primer, da za potrebe odbrane SAD troše koliko i ostatak sveta zajedno, a obim njihove privrede iznosi koliko i japanska, nemačka i britanska privreda zajedno. Naime, sa samo pet procenata svetskog stanovništva SAD ostvaruju 25 odsto svetske proizvodnje.

Tabela 1 - Pregled aktivnih vojnih snaga SAD iz 2008. godine ${ }^{9}$

\begin{tabular}{|l|r|}
\hline \multicolumn{1}{|c|}{ Pripadnost } & \multicolumn{1}{c|}{ Broj } \\
\hline Kopnena vojska & 538.128 \\
\hline Mornarica & 332.832 \\
\hline Mornarička pešadija & 194.912 \\
\hline Vazduhoplovne snage & 328.439 \\
\hline UKUPNO U ORUŻANIM SNAGAMA & $\mathbf{1 . 3 9 4 . 3 1 1}$ \\
\hline Obalska straža & 42.331 \\
\hline UKUPNO U MINISTARSTVU ODBRANE & $\mathbf{1 . 4 3 6 . 6 4 2}$ \\
\hline
\end{tabular}

\footnotetext{
${ }^{6}$ S. Stojanović, isto, str. 163.

${ }^{7}$ M. Danner, „Marooned in the Cold War”, World Policy Journal, XIV 3, 1997, p. 4, u: M. Mandebaum, Ideje koje su osvojile svet, str. 377.

${ }^{8}$ Ž. Ivanović, „Put u carstvo dobra vodi u apokalipsu ”, u: Zbornik Ka carstvu dobra ili apokalipsa, (priredio Ž. Ivanović) Beograd, 2003, str. 16.

${ }^{9}$ Zvanični podaci Ministarstva odbrane SAD za 31. jul 2008. godine, http://siadapp.dmdc.osd.mil/personnel/MILITARY/ms0.pdflzvor:http://money.cnn.com/magazines/fortune/global $500 / 2007 /$ countries/US.html
} 
U svetskoj proizvodnji SAD učestvuju sa 25 procenata. Sa liste Fortune ${ }^{10}$, od 500 najvećih kompanija 162 su američke, 163 pripadaju EU, a 95 Japanu, Kini i Ruskoj Federaciji. Sjedinjene Države imaju gotovo dvostruko više direktnih stranih investicija od sledeće rangirane zemlje (Velika Britanija), a u njima se nalazi i polovina od deset vodećih investicionih banaka. Od 75 vodećih robnih marki, 52 su američke, kao i devet od deset vodećih poslovnih škola. U pogledu meke moći Sjedinjene Države su daleko najveći izvoznik u svetu filmskog i televizijskog programa, a privlače i najviše stranih studenata i profesora. Očigledna je još uvek nedostižna pozicija SAD u odnosu na sve ostale zemlje i njen ključni položaj u svetskoj ekonomiji. Može se pretpostaviti da će Sjedinjene Američke Države u narednih dvadesetak godina zadržati primat u svim činiocima moći i uticaja u svetu, a najduže i najpouzdanije u vojnoj moći. Prema mnogim teoretičarima globalizacije, najznačajniji razlog za opstajanje NATO-a jesu zahtevi krupnog kapitala u smislu obezbeđivanja adekvatnog ambijenta za nesmetano širenje i ničim ograničen pristup neophodnim resursima i energentima. Nestašica strateških resursa i nesuglasice u vezi s vlasništvom nad energetskim izvorima, po svemu sudeći, biće u bliskoj budućnosti sve veći razlog za nastajanje konflikata i sukoba na globalnoj sceni. Galopirajuća potražnja za proizvodima svih vrsta i enormni porast svetske populacije čine realnim takva predviđanja. Uzročna veza između resursa i mogućnosti konflikata uticala je na značajno povećanje koncentracije vojne sile upravo u područjima gde se nalaze najveća svetska nalazišta energenata. Znatno su izmenjene strategije odbrane vodećih zemalja u kojima su energenti tretirani kao geopolitički prioriteti, a radi njihove zaštite podrazumeva se upotreba svih sredstava, „uključujući unilateralnu i odlučnu primenu vojne sile". ${ }^{11} \mathrm{U}$ takvim okolnostima redefiniše se uloga oružanih snaga, pa one postaju ključni činilac u zaštiti ekonomskih interesa vodećih sila, odnosno u osvajanju novih i očuvanju postojećih energetskih izvora. ${ }^{12}$ lako je došlo do značajnih promena u zamisli vezanoj za bezbednost, SAD i ostale zapadne zemlje svoju percepciju mira i stabilnosti zasnivaju na daljoj militarizaciji i tehnološkom usavršavanju vojnih potencijala. Tako, ni u periodu u kojem je, nakon okončanja hladnog rata, obim oružanih snaga smanjen, nije bilo zastoja u unapređivanju vojne tehnologije. Jaz između vojne moći SAD i ostalog sveta veći je nego ikada ranije. To potvrđuje i rast vojnih troškova u periodu od 2001. do 2005. godine. Ukupni vojni troškovi u 2001. godini u svetu iznosili su 839 milijardi dolara, pri čemu su 36-37 odsto tog iznosa potrošile Sjedinjene Države. U tom periodu budžet SAD bio je 25 puta veći nego ruski budžet. ${ }^{13}$ Procenjeni ukupni vojni troškovi u svetu u 2005. godini iznosili su 1.118 milijardi dolara, pri čemu su oko 48 odsto tog iznosa potrošile Sjedinjene Države. ${ }^{14}$

Postoje jasni pokazatelji da se globalna vojna potrošnja povećava u odnosu na stanje sredinom devedesetih godina 20. veka. Porast vojnih troškova u 2005. godini veći je za oko 3,4 odsto u odnosu na 2004. godinu, odnosno za više od 34 odsto u odnosu na 1996. godinu. ${ }^{15}$ Više od 80 odsto povećanja vojnih troškova u 2005. godini odnosi se na troškove SAD u toj oblasti, tj. na angažovanje njenih snaga u Avganistanu i Iraku. Mnoge

\footnotetext{
${ }^{10}$ http://money.cnn.com/magazines/fortune/global500/2007/countries/US.html

${ }^{11}$ S. Stojanović , isto, str. 168.

${ }^{12}$ Isto.

${ }^{13}$ Politika, 10. maj 2006.

${ }^{14}$ SIPRI Yearbook 2006 Armaments, Disarmament and International Security, http.// www.sipri.org.

${ }^{15}$ Isto.
} 
zemlje proizvođači oružja (SAD su najveći izvoznici oružja - oko 100 milijardi dolara godišnje) odlučile su da održe vojnu industriju, pa komercijalizuju vojnu proizvodnju i agresivno povećavaju izvoz oružja. Ukupna vrednost od prodaje naoružanja koju je ostvarilo 100 najvećih kompanija 2004. godine iznosila je 268 milijardi \$. Od istog iznosa 63 odsto ostvarilo je 40 američkih kompanija, a 29 odsto 36 zapadnoevropskih kompanija. Kompanije Rusije i Indije ostvarile su po jedan odsto ukupno ostvarenog iznosa od prodaje naoružanja. ${ }^{16}$

Tabela 2 - Prvih pet kompanija koje su ostvarile najveći transfer u prodaji naoružanja u 2004. godini ${ }^{17}$

\begin{tabular}{|l|l|r|}
\hline \multicolumn{1}{|c|}{ Naziv kompanije } & \multicolumn{1}{|c|}{ Zemlja } & \multicolumn{2}{c|}{$\begin{array}{c}\text { Iznos ostvaren od prodaje naoružanja u } \\
\text { milijardama dolara }\end{array}$} \\
\hline Boeing & SAD & \multicolumn{2}{c|}{27,5} \\
\hline Lockheed Martin & SAD & 26,4 \\
\hline Northrop Grumman & SAD & 26,0 \\
\hline BAE Systems & Velika Britanija & 19,8 \\
\hline Raytheon & SAD & 17,2 \\
\hline
\end{tabular}

Značajna je činjenica da je u periodu od 1998. do 2001. godine više od 68 odsto $^{18}$ ukupnog transfera naoružanja u svetu bilo prodato ili dato nerazvijenom svetu, što je uticalo na intenziviranje konflikata i nasilja u tim zemljama. Na taj način umnožavanje oružanih konflikata i ekonomsko iscrpljivanje najsiromašnijih regiona Afrike i Latinske Amerike još više otežava proces političke stabilizacije ogromnih prostora savremenog sveta. Nije teško zaključiti da Sjedinjene Države, kao država čija je dominacija u trgovini naoružanjem nesporna i koja na taj način ostvaruje ogromne profite, utiču na povećanje nestabilnosti u mnogim delovima sveta i pospešuju militarizaciju međunarodnih odnosa.

Intenziviran je novi talas trke za ekskluzivnim posedovanjem oružja, pri čemu je uvećana opasnost od rata i razaranja. Procenjeno je da se više od 800 milijardi dolara godišnje utroši za potrebe naoružanja i održavanja vojne sile u svetu. Tako je u okviru predloga američkog budžeta za 2007. godinu najveće povećanje - od 4,8 odsto predviđeno za potrebe Pentagona. U predlog američkog vojnog budžeta od oko 441 milijarde dolara nije uključeno finansiranje ratova u Iraku i Avganistanu, čiji troškovi iznose desetine milijardi dolara. ${ }^{19}$ Planirano je da budžet odbrane SAD narednih godina kontinuirano raste, tako da 2010. godine treba da iznosi više od 514 milijardi dolara. ${ }^{20}$ Kako kaže Volerstin, supersila „čiji je jedini važniji zahtev da bude vojno superiorna na svetskoj sceni mora da afirmiše i afirmisaće trajna ulaganja u vojnu opremu". ${ }^{21}$ Nestanak bipolarnog sveta i tendencije jačanja vojne moći u međunarodnim odnosima aktuelizovali su nadmetanje za regionalnu dominaciju, pre svega među državama istočne i jugoistočne Azije, gde je in-

\footnotetext{
${ }^{16}$ Isto, str. 169.

${ }^{17}$ SIPRI Yearbook 2006 Armaments, Disarmament and International Security, http.// www.sipri.org

${ }^{18}$ Fast Facts.htm.

${ }^{19}$ The Military Balance 2005-2006, p. 37.

${ }^{20}$ Isto.

${ }^{21}$ S. Sojanović i S. Nikolić, „Nova globalna podela moći”, Beograd, 2009, str. 7.
} 
tenzivirana trka u naoružanju, a najilustrativnije primere predstavljaju Indija i Pakistan. Slični procesi postoje i u Africi, gde sada, prema nekim procenama, ima 100 puta više oružja nego pre 40 godina. Isto tako, primetno je da se, uporedo s jačanjem globalnih ekonomskih procesa, nadmetanje između država delimično potiskuje nadmetanjem između ekonomskih blokova. Misli se, pre svega, na SAD, EU i Japan, koji bi, prema nagoveštajima u nekim radovima o globalizaciji, vremenom mogli da prerastu u političke saveze i blokove. Mandelbaum navodi podatak da na početku 21. veka „od gotovo dvesta suverenih država u međunarodnom sistemu tri četvrtine pripadaju periferiji”, ${ }^{22}$ i da sve one, iako postoje razlike među državama sa periferije, nastoje da se prilagode ekonomskom i političkom standardu međunarodnog liberalizma. Za Mandelbauma su brojnost i ekonomska nerazvijenost država „periferije”, kao i njihova manja posvećenost demokratiji, slobodnom tržištu i miru, bili sa stanovišta stabilnosti novog svetskog poretka glavni razlozi za njihovo preobraćanje. Time je potreba da se „model neoliberalizma izveze na periferiju postao glavni prioritet spoljne politike SAD" 23 . Uverenost Amerike u ekskluzivnost svoje misije zasnovana je na stavu da je ona glavna politička, ekonomska i vojna potpora liberalnih vrednosti, načela i institucija. Budući da je posedovala zaokruženu globalnu moć i da nije imala ozbiljnijeg rivala, Amerika je zaista, kako misli znatan broj teoretičara, započela svoj treći vek učestvovanja u međunarodnom životu kao Imperium Americana. Takva međunarodna pozicija omogućila joj je da kreira i usmerava tok političke i vojno-bezbednosne globalizacije i međunarodnih odnosa u celini, tako da se od trenutka iščezavanja bipolarnog američko-sovjetskog „poretka sveta” može govoriti o amerikanizaciji međunarodnih odnosa. $^{24}$

Međutim, takva konstelacija unipolarnih međunarodnih odnosa činila je realnom opasnost od totalitarističkih tendencija u spoljnoj politici SAD i njene spremnosti da se suprotstave svima koji bi joj uputili izazov i doveli u pitanje njenu poziciju hegemona i odlučujuću reč u rešavanju vitalnih pitanja sveta. Unipolarnim delovanjem u spoljnoj politici i agresivnom promocijom demokratije, SAD su od države koja je u poslednjih pola veka bila uzor u poimanju demokratije i prosperitetne ekonomije za celo čovečanstvo postala metafora međunarodnog nereda, proizvodeći nesigurnost i sukobe. Aktuelna finansijska kriza, platni deficit veći od bilion dolara i nadolazeće ekonomsko razlaganje koje sledi u $S A D$, neuspesi misija u Iraku i Avganistanu, kao i degradacija američkih kulturnih vrednosti nagoveštavaju prognoze o zalasku moći ove doskora neprikosnovene supersile. Irak i Avganistan su danas zemlje haosa sa situacijom koja postaje sve složenija. Odluke američke vlasti o ukidanju subvencija za hranu, amerikanizaciji celokupne poljoprivredne proizvodnje, podeli najunosnijih naftnih, energetskih i uslužnih poslova zaslužnim korporacijama, otpuštanju desetine i desetine hiljada državnih službenika i radnika, te slabi pomaci na poboljšanju infrastrukture, učinili su ove zemlje jednim od najsiromašnijih i najtežih mesta za život. Zbog pobunjeničkih napada Irak je, početkom 2005. godine, proizvodio naftu svega pola miliona barela dnevno, što je mnogo više od 1,5 miliona barela, kolike su trenutne mogućnosti. Talibani i Al-Kaida preuzimaju inicijativu, koju su prepustili

\footnotetext{
${ }^{22}$ M. Mandelbraun, „Ideje koje su osvojile svet”, Filip Višnjić, Beograd, 2004, str. 80.

${ }^{23}$ Isto.

${ }^{24}$ D. Nikoliš, „O globalizaciji kao političkom ( i geopolitičkom i vojnobezbednosnom ) fenomenu međunarodnih odnosa i Sjedinjenih Država u njima”, u: Vreme globalizacije, str. 187.
} 
američkim snagama u periodu po otpočinjanju kampanje u Avganistanu. Svakodnevni napadi povećavaju strah kod stanovništva od odmazde i udaljuju ga od međunarodnih snaga, posebno SAD. Trgovina drogom i drugi oblici kriminala dostigli su obim i nivo koji su imali pre intervencije, a vojne i policijske snage su preslabe da se nose sa velikim brojem militantnih kriminalnih grupa. Sjedinjene Države su do 2009. godine samo za operaciju u Iraku potrošile oko 845 milijardi dolara, što je oko 2.300 dolara po stanovniku, tj. prosečno 2,2 miliona dolara nedeljno ili oko 8,8 milijardi dolara mesečno. Pošto oružja za masovno uništenje definitivno nema, prosečan Amerikanac počinje da shvata da je rat vođen isključivo zbog nafte, koje nema zbog stalnih sabotaža i nemogućnosti njenog transporta od izvora do rafinerije. Zbog ovakve situacije SAD traži načina da se izvuče iz Iraka i Avganistana, što je svojevremeno nagovestio i američki predsednik Barak Obama.

\section{Ubrzani rast vojne moći Kine}

Mnogi vide Kinu, najmnogoljudniju državu, kao vodećeg kandidata za ulogu globalnog lidera u 21. veku. Za mnoge je „uspon Kine” pogrešan izraz, a „ponovna pojava Kine " tačnija sintagma, jer je po veličini i istoriji Srednje kinesko kraljevstvo dugo bilo vodeća sila u istočnoj Aziji. Poznato je da je tehnički i ekonomski Kina bila svetski lider, iako bez globalnog dometa od 500 . do 1500 . godine. Tek u poslednjih pola milenijuma pretekle su je Evropa i Amerika. ${ }^{25}$ Kina je najbrojnija zemlja sveta sa više od jedne milijarde i 300 miliona stanovnika. Po veličini teritorije ona je treća zemlja. Ima najbrojniju armiju sa više od dva miliona vojnika. Uspon Kine je rezultat temeljnih privrednih reformi koje su preduzimane u poslednje tri decenije. O pravom ekonomskom bumu uverljivo govore sledeći pokazatelji. Kineski udeo u rastu svetske privrede u 2004. godini dostigao je čak jednu trećinu, a u 2005. godini Kina je ostvarila privredni rast od 9,9\%. Prema podacima za 2006. godinu kineska privreda je zabeležila rast od oko $11 \%$.

Visoka godišnja stopa rasta od 8 do 11 procenata dovela je do zadivljujućeg utrostručavanja njenog nacionalnog bruto proizvoda u poslednje dve decenije. U 2007. godini ostvarila je bruto domaći proizvod (BDP) od 3.280 milijardi dolara i po tome bila četvrta ekonomija u svetu. U 2010. godini Kina je po ostvarenom BDP pretekla Nemačku i Japan i pozicionirala se odmah iza SAD.

Prema izveštaju Organizacije za ekonomsku saradnju i razvoj, Kina je već više od godinu dana najveći svetski izvoznik tehnologije. Ova organizacija je evidentirala da SAD zaostaju za Kinom za čitavih 30 milijardi dolara samo u sektoru "high-tech" koji se odnosi na mobilne telefone, lap-topove, digitalne fotoaparate, itd. U 2004. godini ostvarila je obim izvoza u ovom sektoru od 180 milijardi dolara, dok su SAD ostvarile 149 milijardi. Samo godinu dana ranije, u 2003. godini, Kina je bila na drugom mestu sa 123 milijarde, iza SAD, koje su imale izvoz od 137 milijardi dolara. Kineska kvota u globalnim trgovačkim razmerama u isto vreme dostigla je brojku od 329 milijardi dolara, što predstavlja godišnji rast od 95 milijardi dolara. Poređenja radi, u 1996. godini ta brojka je iznosila samo 35 milijardi dolara. Više od 27 odsto tehnološkog uvoza u SAD nosi oznaku „Made in China”, a u 2000. godini on je iznosio manje od 10 odsto. Od 2001. godine, kada je Kina zvanično ušla u Svetsku trgovinsku asocijaciju

${ }^{25}$ Dž. S. Naj, „Paradoks američke moći”, BMG Beograd, 2004, str. 41-42. 
(STO), njena privreda doživljava verovatno najveći ekonomski bum svih vremena. Zahvaljujući najkonkurentnijim cenama, Kina osvaja ne samo bogate zemlje, već i siromašne zemlje Afrike. Zahvaljujući komercijalnom otvaranju, kineski gigant postaje, na neosporan način, svetski dominantan u planetarnoj trgovini. To je napredak koji će omogućiti Kini da u svim sektorima prevaziđe Evropsku uniju i SAD pre 2050. godine. Realno je očekivati da će ekonomska moć doprineti jačanju političke i vojne moći, što potvrđuje i rast finansijskih sredstava za odbranu za 12, 6\% u 2006. godini. Izvršeno je i znatno smanjenje i reformisanje snaga kineske armije, a težište je na modernizaciji vojne opreme i naoružanja. U 2015. godini kineski izdaci za vojsku bili su šest puta veći od japanskih, a njen akumulirani vojni kapital je oko pet puta veći od japanskog. Zalivski rat 1991. godine, napetosti oko Japana 1995. i 1996. godine i bombardovanje SRJ 1999. godine pokazali su kineskim liderima koliko njihova zemlja zaostaje u modernim vojnim kapacitetima, pa su gotovo udvostručili vojne rashode tokom poslednje dve decenije. ${ }^{26}$ Kina danas aktivno nastoji da ograniči moć Sjedinjenih Država u istočnoj Aziji upozoravajući na opasnost od američke unipolarne spoljne politike po međunarodne odnose. Tokom 2001. godine svetska političko-bezbednosna konstelacija sa institucionalnom predominacijom evroatlantskih političko-ekonomsko-bezbednosnih struktura i potencijala, „poremećena” je pojavom jedne organizacije, samo naizgled regionalnog značaja i delovanja - Šangajske organizacije za saradnju, koja okuplja predstavnike Kine, Rusije, Uzbekistana, Kazahstana, Kirgizije i Tadžikistana. Posebno je važno naglasiti da status posmatrača imaju Iran i Avganistan. Ova organizacija je početkom januara 2004. godine za svoje sedište odredila prestonicu Kine - Peking. Kina i Rusija su našle zajednički interes za jačanje regionalne saradnje, kako bi se uspešnije suprotstavile uticaju SAD u njihovoj geografskoj, političkoj, ekonomskoj i vojnoj zoni uticaja. lako se naglašava da se Šangajska organizacija za saradnju bavi pitanjima prevashodno političkog i ekonomskog, a bitno manje pitanjima vojnog karaktera, ona je već faktor koji unosi nove dimenzije u evroatlantske geopolitičke kalkulacije. Možda još značajniji aspekt delovanja „Šangajske šestorke” jeste impuls ekonomske saradnje i integracije ruskog i kineskog privrednog prostora. Radi se o enormnim sirovinskim, proizvodnim i ljudskim resursima, ali i tržištima koja su u fazi ogromne ekspanzije. U njenim državama članicama živi otprilike jedna četvrtina ukupnog svetskog stanovništva. Šest zemalja ove asocijacije poseduje 8 odsto poznatih svetskih rezervi nafte i 31 odsto rezervi prirodnog gasa. Kineska armija je najveća na svetu, a ruska aktivna vojska je četvrta po veličini. Uprkos tome što zvaničnici to povremeno negiraju, politička i vojna koordinacija postaje sve prepoznatljiviji znak ove organizacije. Mora se priznati da su američka hegemonska politika i ambicije za globalnom vojno-političkom dominacijom, kroz formu borbe protiv terorizma, inspirisala dve narastajuće svetske velesile - Rusiju i Kinu da uobliče zajednički regionalni, ali i znatno širi bezbednosno-politički interes. Šangajska organizacija za saradnju predstavlja snažan impuls ukidanju globalne unipolarnosti i političko-ekonomsko-vojne supremacije evroatlantskih struktura koje predvode SAD. Ipak, Kina, i pored značajnog ekonomskog rasta, zaostaje za Sjedinjenim Državama i svoje politike prevashodno usredsređuje na svoj region i ekonomski razvoj. Ona treba da pređe dug put i suoči se sa mnogim preprekama u svom razvoju. Prema predviđanjima, ako američka privreda raste po stopi od dva procenta, a kineska raste po stopi od 9 procenata (u najboljem slučaju), dve privrede će biti jednake veličine (po BDP-u) oko 2028. godine. Čak i tada dve privrede bi bile jednake po veličini, ali ne i jednake u konkurentnosti.

\footnotetext{
${ }^{26}$ S. Stojanović i S. Nikolić , isto, str. 10.
} 
Kina bi još uvek imala veliku nerazvijenu unutrašnjost - u stvari, pretpostavljajući kineski rast od 9 procenata i američki rast od samo dva procenta, Kina bi se izjednačila sa Sjedinjenim Državama u dohotku po glavi stanovnika oko 2056. godine. U pogledu političke moći dohodak po glavi stanovnika pruža precizniju meru modernizacije privrede. Kineski dohodak po glavi stanovnika biće jednak današnjem u SAD do 2045. godine, što dovodi do zaključka da je Kina daleko od ugrožavanja američke ekonomske nadmoći. Naime, prema mišljenju nekih teoretičara, rastuća nejednakost, ogromne interne migracije i nezadovoljavajuća mreža socijalne zaštite, korupcija i neodgovarajuće institucije mogu da aktiviraju političku nestabilnost Kine. Nemogućnost kontrole demografskog rasta, tokova migracije, ekoloških efekata na globalnu klimu i porast broja internih konflikata predstavlja još jedan skup problema koji mogu imati negativan uticaj na razvoj Kine. Isto tako, visoka stopa rasta privrede, u bliskoj budućnosti biće podložna iscrpljivanju ključnih prirodnih resursa koji već danas nedostaju Kini. Bez obzira na impresivne podatke rasta vojne moći, smatra se da je malo verovatna opcija da Kina ugrozi vojnu superiornost SAD. Ključ vojne moći u informatičkoj eri zavisi od sposobnosti prikupljanja, obrade, širenja i integrisanja podataka iz složenih sistema nadgledanja iz svemira, računara velike brzine i „pametnog” oružja. lako će Kina razviti neke od tih sposobnosti, smatra se da će revolucija u vojnim poslovima nastaviti da održava veliku američku vojnu nadmoć. Međutim, bez obzira na osporavanja njenog uspona, koja, pre svega, dolaze od zapadnih teoretičara, izvesno je da Kina sve značajnija sila koja nikoga ne ostavlja ravnodušnim. Otuda su objektivne procene koje govore da će prva polovina 21. veka biti obeležena kao decenije Kine. U tom smislu, sve je izvesnije da će uspon Kine biti u znaku utiskivanja kineskog pečata na kretanja tokova savremenog sveta dublje i trajnije nego bilo koji drugi savremeni procesi i promene.

\section{Restauracija vojne moći Rusije}

Polazna tačka svakog procenjivanja strategijskih izgleda Rusije jeste prepoznavanje toga koliko je ona postala slaba, pre svega, u odnosu na mesto koje je zauzimala kao jezgro Sovjetskog Saveza. Lišena svog ogromnog carstva u istočnoj Evropi, na Kavkazu i srednjoj Aziji, Rusija je krajem poslednje decenije 20. veka bila tek bleda senka preteće supersile koja se nekad nadmetala sa Sjedinjenim Državama za globalnu prevlast. Tokom 50-ih godina mnogi ljudi na Zapadu su se plašili da bi Sovjetski Savez mogao prestići SAD kao vodeću svetsku silu. Sovjetski Savez je imao najveću teritoriju na svetu, treću najveću populaciju, drugu najveću privredu i proizvodio je više nafte i gasa od Saudijske Arabije. Posedovao je polovinu svetskog nuklearnog oružja, više vojnika od Sjedinjenih Država i najveći broj ljudi zaposlenih u istraživanju i razvoju. Testirao je hidrogensku bombu 1953. godine, samo godinu dana nakon Sjedinjenih Država, a prvi je lansirao satelit u svemir 1957. godine. Komunistička ideologija Sovjetskog Saveza i njegova transnacionalna organizacija doneli su mu prestiž u Evropi zahvaljujući otporu Hitleru, a u zemljama trećeg sveta njegova identifikacija sa popularnim pokretom ka dekolonijalizaciji činila ga je veoma privlačnim. ${ }^{27}$ Raspad Sovjetskog Saveza 1991. godine ostavio je Rusiju sa znatno smanjenom teritorijom (76 procenata SSSR-a), stanovništvom (50 proce-

${ }^{27}$ Dž. S. Naj, „Paradoks američke moći”, BMG Beograd, 2004, str. 52-53. 
nata SSSR-a), privredom (45 procenata SSSR-a) i vojskom (33 procenta SSSR-a). Pored toga, ideološka moć komunističke ideologije praktično je nestala. Na kraju veka ispostavilo se da je privreda SAD oko 27 puta veća od ruske, da je njihova potrošnja na istraživanje i razvoj oko 60 puta veća nego u Rusiji, a da su vojni izdaci oko 9 puta veći. ${ }^{28} \mathrm{Ru}$ sija je ipak zadržala neka obeležja velike sile. Više nije okovana komunističkom ideologijom i glomaznim sistemom centralnog planiranja. Verovatnoća etničke fragmentacije, mada još uvek pretnja (kao što su pokazali ratovi u Čečeniji), smanjena je. Dok su etnički Rusi činili samo polovinu stanovništva Sovjetskog Saveza, danas čine 81 procenat stanovništva Ruske Federacije. Sa oko 146 miliona stanovnika i teritorijom koja se proteže na preko 11 vremenskih zona, ona je i dalje prvi geopolitički subjekt u središtu Evroazije. $U$ drugoj polovini devedesetih godina otpočeo je ekonomski oporavak Rusije i njen povratak na geopolitičku scenu. Bruto društveni proizvod rastao je šest do sedam odsto godišnje. Uporedo je porastao i njen zvanični vojni budžet - sa 6,7 milijardi dolara u 1997. godini na oko 12 milijardi u 2003. godini. U 2007. godini vojni budžet RF iznosio je oko 20 milijardi dolara. Vojnoekonomski analitičari zapadnih zemalja procenjuju da su realni vojni izdaci RF znatno veći od zvaničnog budžeta, iz kojeg se ne finansiraju sve aktivnosti. Međunarodni londonski Institut za strategijske studije procenjuje da su vojni izdaci RF u 2006. godini dostizali 75,6 milijardi dolara, što po veličini predstavlja drugi izdatak u svetu. Ruska Federacija poseduje veliki i moćan nuklearni arsenal - odmah iza onog koji poseduju Sjedinjene Države - i stotine interkontinentalnih balističkih raketa. Ona je još uvek najveći dobavljač konvencionalnog oružja i nuklearne tehnologije za mnoge države, među kojima su Kina, Iran i Indija.

Rusija nadzire ogromne rezerve nafte i prirodnog gasa, uz veliku mrežu naftovoda koji povezuju Kaspijsko jezero i srednju Aziju sa istočnom i zapadnom Evropom. ${ }^{29}$ Za Rusiju je energetska superiornost od strateškog značaja jer joj omogućava da sačuva svoju nezavisnost i povrati kredibilitet velike sile u međunarodnim odnosima. Ona preduzima sve što je neophodno kako bi zadržala vodeće pozicije u proizvodnji i preradi nafte i gasa., Stabilno i pouzdano snabdevanje energentima danas ima izuzetan značaj za svaku zemlju. Industrija nafte i gasa je jedan od najvećih sektora ruske privrede koji dinamično raste, a njen efikasan rad određuje umnogome osiguranje životnih potreba države. Dovoljno resursa Rusija može da koristi za rešavanje ključnih pitanja - od osavremenjivanja ekonomije, rešavanja socijalnih problema, modernizacije oružanih snaga, do podrške ruskog biznisa na svetskom tržištu. Ogroman izvozni potencijal ruske industrije nafte i gasa ima značajnu ulogu u energetskoj stabilnosti evroazijskog kontinenta i celog sveta. To joj omogućava da u svojoj spoljnoj politici Rusija prvi put u svojoj istoriji brani svoje interese koristeći svoje konkurentske prednosti. Upravo je u sferi energetske politike Moskva daleko iznad svog međunarodnog uticaja. Sa izvozom nafte i prirodnog gasa koji danas osiguravaju najveći deo ruskog prihoda - 55\% prihoda od izvoza i $40 \%$ državnih prihoda, ${ }^{30}$ Moskva čini sve što može da poveća svoju proizvodnju energije kako bi obezbedila dodatna sredstva za ekonomsku i političku revitalizaciju. Rusija je iskoristila izvoz energije i kao sredstvo za učvršćivanje veza sa uticajnim stranim potrošačima kao što su

\footnotetext{
${ }^{28}$ S. Stojanović i S. Nikolić, isto, str. 12.

${ }^{29}$ M. T. Kler, Krv i nafta, Znanje, Zagreb, 2005, str. 176.

${ }^{30}$ Isto, str. 14.
} 
Nemačka i Japan. Rusija pokušava da sačuva monopol nad transportom nafte i gasa iz Kaspijskog basena na zapad, nastojeći da što je moguće više osujeti razvoj bilo koje alternativne rute koja bi zaobišla Rusiju. ${ }^{31}$ Rusija traži novu svetsku multipolarnu strukturu naspram američke „dominacije”, kao i mogućnost da povrati svoj uticaj u „postsovjetskom prostoru”. Međutim, imajući u vidu da i SAD smatraju taj prostor „zonom američkog interesa" i obezbeđuju značajna ekonomska i druga sredstva da bi ga ojačali, Rusija intenzivira proces unapređenja svojih odnosa sa moćnim susedima. Rusija je sa Kinom 1992. godine obelodanila svoje odnose „konstruktivnog partnerstva”, 1996. godine ove dve zemlje proklamovale su „strateško partnerstvo”, a u julu 2001. godine potpisale su sporazum o „prijateljstvu i saradnji”. Tema partnerstva je suprotstavljanje „unipolarnom svetu" kojim dominiraju SAD. lako su i Rusija i Kina podržale američku antiterorističku kampanju posle septembra 2001. godine, ostale su podozrive prema američkoj moći. ${ }^{32} \mathrm{U}$ analizi povratka Rusije na međunarodnu scenu američki analitičari smatraju da će i u slučaju najboljeg scenarija godišnjeg privrednog rasta od 7 procenata, Rusija imati BDP koji danas imaju SAD do 2033. godine. Međutim, Rusija predstavlja pretnju za interese SAD, pre svega jer je to jedina zemlja sa dovoljno projektila i nuklearnih bojevih glava za uništenje SAD. Rusija takođe ima ogromna prostranstva, obrazovano stanovništvo, stručne naučnike i inženjere i velike prirodne resurse. Međutim, prema mišljenju američkih teoretičara, povratak Rusije na geopolitičku scenu, ne predstavlja istu vrstu izazova američkoj moći kakvu je Sovjetski Savez predstavljao tokom četiri decenije nakon Drugog svetskog rata. Rusija želi da bude velika sila, što u uslovima XXI veka znači i nezavisni globalni igrač. Rusko rukovodstvo je poslednjih godina odlučilo da opozove raniju rusku strategiju integracije sa Zapadom. Ta odluka bila je zasnovana na generalnom načinu na koji rusko rukovodstvo shvata odnose Rusije i Zapada od ranih devedesetih godina prošlog veka do prvih godina XXI veka. Rusko odvajanje od Zapada dogodilo se, naravno, u uslovima američkog rata u Iraku, državi sa trećim najvećim rezervama nafte na svetu. Do sredine prve decenije ovog veka energija je igrala ključnu ulogu u preorijentaciji Rusije od prozapadne prema nezavisnoj velikoj sili. Kako bi postigla postavljeni cilj strateške nezavisnosti i međunarodnog značaja, što je, na primer, oličeno u postavljanju cilja da postane peta najveća privreda na svetu do 2020. godine - Rusija je odlučna da iskoristi svojih nekoliko, ali važnih komparativnih prednosti, pre svega naftu i gas. Rusija poseduje nešto preko 6 posto dokazanih svetskih rezervi nafte i 2006. je zabeležila 12 procenata svetske proizvodnje nafte. Takođe, poseduje jednu četvrtinu svetskih rezervi prirodnog gasa i odgovorna je za jednu petinu ukupne proizvodnje gasa u svetu. Ekstra-profiti od izvoza energije omogućili su Rusiji da stekne finansijsku moć, a prateći stimulativni efekti pogodovali su mnogobrojnim drugim sektorima privrede. Međutim, vlada je veoma svesna potrebe da modernizuje sektore nafte i gasa i da postigne napredak u razvoju ostalih segmenata energetskog sektora, kao što je „čisti” ugalj i međunarodno konkurentna nuklearna energija. Ruska specijalizacija za energiju je konstanta, zasigurno na srednji i duži rok. Rusko rukovodstvo pretpostavlja da će međunarodne cene energije ostati na visokom nivou neko vreme, uprkos povremenim fluktuacijama. Alternativni izvori energije, osim nuklearne energije, u dogledno vreme neće imati veći uticaj na tržište. Uz to, kada

\footnotetext{
${ }^{31}$ Isto.

${ }^{32}$ S. Džozef Naj, Paradoks američke moći, BMG Beograd, 2004, str. 50.
} 
se radi o nuklearnoj energiji, ali i uglju i proizvodnji struje, Rusija zauzima snažnu poziciju. Označavanje Rusije kao energetske supersile je preterivanje, ali je kredibilna ocena Rusije kao energetske sile, pogotovo ukoliko uspe da unapredi proizvodnju i postane efikasniji potrošač. Međutim, prema mišljenju američkih teoretičara, povratak Rusije na geopolitičku scenu ne predstavlja istu vrstu izazova američkoj moći kakvu je Sovjetski Savez predstavljao tokom četiri decenije nakon Drugog svetskog rata. Zbog svoje preostale nuklearne snage, bliskosti sa Evropom i potencijalne alijanse sa Kinom ili Indijom, Rusija ne može da ne bude globalni izazivač. Novi raspored snaga na međunarodnoj areni postao je sasvim jasan tokom avgusta 2008. godine. Petodnevni rusko-gruzijski rat učinio je očiglednim povratak Rusije, kao i oslabljenu moć SAD da spreči poraz proameričkog režima u Gruziji. Kina je 2003. godine postala drugi najveći potrošač nafte iza SAD. U izveštaju iz 2006. godine Svetska agencija za energiju (IEA) upozorava kako će, s obzirom na sadašnji rast, Kina prestići SAD u emisiji staklenih gasova 2009. godine, čak 10 godina pre predviđenog roka. Još 2005. godine pretekli su SAD u potrošnji žita, mesa, uglja i gvožđa. Po sadašnjim trendovima potrošnje, velike pretenzije za energetskim resursima i zagađenju okoline Kina se predstavlja svetu kao mlađa verzija američkog sna. Kina je 2004. godine imala 63 milijarde dolara gubitka zbog zagađenja i ekoloških incidenata, najviše kao posledica zagađenja vode i vazduha. Jedna trećina Kine pati zbog kiselih kiša koje nastaju zbog preteranog emitovanja ugljen-dioksida iz termoelektrana na ugalj. Emisija tog gasa je dvostruko veća od bezbednosnog nivoa, te je u porastu za 27 posto u odnosu na 2000. godinu. Već sada Kina koristi više uglja nego SAD, EU i Japan zajedno. Pri tome je emitovanje ugljen-dioksida dvostruko više nego u SAD. Više od 300 miliona seoskog stanovništva nema pristup pitkoj vodi, a 400 miliona gradskih stanovnika udiše jako zagađen vazduh (od toga in 15 miliona boluje od bolesti respiratornog organa).

Kina je danas uvoznik hrane, a 2005. godine proizvela je 34 posto manje žitarica u odnosu na 1998. godinu. Razlozi su povezani sa zagađenjem vazduha, vode i zemlje. Samo u razdoblju 1999-2005. Kina je izgubila 8 miliona hektara plodnog zemljišta koje se zbog industrijalizacije i loše poljoprivredne politike pretvaralo u pustinjska područja. Ovi podaci govore da su u ovom trenutku Kinezi ipak najveća opasnost sami sebi. Jasno je da kineska potrošnja raste i da je emisija staklenih gasova sve veća, ali je danas uticaj Kine na klimatske promene još uvek mnogo manji od uticaja SAD i većine zemalja EU u odnosu na broj stanovnika.

\section{Evropska unija kao globalni konkurent Sjedinjenim Državama}

Evropa bi po svojoj moći mogla biti ravnopravna sa Amerikom. Prema mišljenju brojnih teoretičara savremenih međunarodnih odnosa, početkom 21. veka Sjedinjenim Državama najviše se približila Evropska unija (EU). lako je američka privreda četiri puta veća od nemačke, najveće evropske države, privreda Evropske unije je veća od privrede Sjedinjenih Država, njeno stanovništvo je znatno veće, kao i udeo u svetskom izvozu. Ove razmere će porasti ako se, kao što je planirano, Evropska unija postepeno proširi i uključi države zapadnog Balkana tokom naredne decenije. Evropa troši oko 2/3 američkih izdataka na odbranu, ima više vojnika i obuhvata dve zemlje koje poseduju nuklearni arsenal. ${ }^{33}$

\footnotetext{
${ }^{33}$ S. Sojanović i S. Nikolić, Isto, str. 15.
} 
U pogledu meke moći evropske kulture su dugo bile široko prihvaćene u ostatku sveta, a osećaj Evrope ujedinjene oko Brisela vrlo je privlačan za Tursku i ostale zemlje kandidate i potencijalne kandidate za članstvo. Tamošnje vlade i ljudi počeli su da oblikuju svoje politike, usklađujući in sa Briselom. Veličina Evrope u geopolitičkom, ekonomskom i društvenom smislu sasvim je očigledna. Ali, integracija interesa suverenih država s tog prostora, ostvarena putem zajedničkih institucija, mogla bi, takođe, poslužiti kao primer ostatku sveta. Na primer, način na koji je Evropa procesom proširenja iskoristila svoju moć kako bi na čitavom kontinentu bio ostvaren dugoročni mir i kako je ubrzala razvoj integracijom čitavih ekonomija, država i društava u svoj institucionalni okvir, mogao bi da postane model za uobličenje svetskog poretka u 21. veku, utemeljenog na saradnji. Ovaj savremeni, napredni i miroljubivi model jedinstven je i superioran u odnosu na sve postojeće pristupe osnovnim pitanjima političkog poretka.

Uporedo sa ostvarivanjem planova za ujedinjavanje Evrope i integracionim procesima koji su utemeljeni u Evropskoj uniji i formulisani u vizijama buduće evropske federacije sa svim važnim atributima državne organizacije, pokrenuto je i pitanje tzv. sistema evropske odbrane. Pod tom inicijativom podrazumeva se pitanje formiranja oružanih snaga Evropske unije u čiji bi sastav ušle nacionalne vojne strukture njenih članica. Suština takvih napora u vezi je s činjenicom da ekonomska moć nije dovoljna za izrastanje EU u globalnog činioca. Svoju ekonomsku moć EU želi da pretoči u vojnu moć, jer tek sa razvojem sopstvene oružane komponente nesporna globalna ekonomska moć može EU da obezbedi ključnu političku moć u svetskim razmerama. Prema tome, suština formiranja autonomnih oružanih snaga sa komandnom strukturom i političkim usmerenjem, formalno nezavisnim od NATO-a, jeste nastojanje da se dostigne strateška jednakost s Amerikom i tako stvore uslovi da EU od „američkog protektorata” postane ravnopravan partner. ${ }^{34}$ Kao unija 27 država, sa više od 500 miliona stanovnika, koja ostvaruje četvrtinu svetskog bruto nacionalnog dohotka i ima na raspolaganju mnoštvo različitih sredstava, Evropska unija je, sasvim sigurno, globalni činilac. U 2003. godini budžet EU za vojne potrebe iznosio je više od 160 milijardi dolara, ona obezbeđuje $37 \%$ budžeta OUN i njene trupe čine $17 \%$ snaga angažovanih u mirovnim misijama ${ }^{35}$. Otuda nastojanje Evrope da preuzme deo odgovornosti za globalnu bezbednost, u okviru koje sve značajnije mesto zauzima energetska bezbednost. lako se taj proces odvija uz mnogo zastoja, izvesno je da se sve jasnije pojavljuje još jedna velika vojna struktura. Evolucija identiteta odbrane i bezbednosti Evrope ima tri dela: Severnoatlantski savez, organizovan tako da obezbeđuje odgovornost Evrope u vezi s pitanjima odbrane; zajednička spoljna politika i politika bezbednosti unutar Evropske unije i jaka Zapadnoevropska unija, operativno sposobna da održava političku kontrolu i strategijski usmerava operacije tipa Petersberg koje su preduzeli Evropljani. Takve operacije obuhvataju humanitarne akcije i akcije spasavanja - uključujući i evakuaciju i pomoć u slučaju elementarnih nepogoda, kao i očuvanje mira i zadatke borbenih snaga u kriznim situacijama. Nova strategija odbrane EU, čije je donošenje obrazloženo izmenjenim karakterom pretnji evropskoj bezbednosti, usmerena je na zaštitu kritičnih evropskih resursa i infrastrukture, kao što su energija, voda, hrana, zdra-

\footnotetext{
${ }^{34}$ U. Kremer, „Novi NATO - novi ratovi”, Beograd, 2000, str. 58.

${ }^{35}$ S. Gligorijević, „Evropska bezbednosna i odbrambena politika”, Seminar o Evropskoj bezbednosnoj i odbrambenoj politici, Ministarstvo odbrane Republike Srbije, decembar 2006.
} 
vlje i transportni sistem. U strategiji odbrane EU jasno su naglašene njene globalne ambicije. U vezi s tim, bliska saradnja između glavnih aktera i partnera ima suštinski značaj za dalje jačanje evropskog bezbednosnog i odbrambenog identiteta, pri čemu su partnerski odnosi sa NATO-om izuzetno važni za EU s obzirom na ambiciju unije da angažovanjem svojih snaga u prevenciji konflikata i upravljanju krizama ima sve zapaženiju ulogu, kao i u jačanju i očuvanju globalnog mira i bezbednosti. Zbog toga se u sporazumu „Berlin plus" podrazumeva potreba da se zajednički formulisana politika EU usklađuje s politikom NATO-a i na taj način obezbedi racionalno angažovanje neophodnih snaga. Problemi koji opterećuju odnose EU i NATO jesu postojeće transatlantske tenzije, različite vizije bezbednosti i nadmetanja oko resursa. Međutim, teško je poreći pozitivan uticaj proširenja EU na stabilnost evropskog prostora, posebno na proces demokratske tranzicije prostora jugoistočne Evrope i stvaranja bezbednosne zajednice. To je ključna pretpostavka na kojoj se zasnivaju zahtevi za širenjem odnosa bezbednosne zajednice na ostala područja Evrope i područja izvan evropskog kontinenta. Ima osnova da se veruje da će se uključivanjem drugih naroda i država starog kontinenta u porodicu evropskih naroda unaprediti ukupna bezbednost tih prostora. ${ }^{36}$ Naravno, proces proširenja EU ima i negativne efekte koji se, pre svega, reflektuju na način donošenja odluke i dostizanja adekvatnog stepena opremljenosti i mobilnosti vojnih snaga. Posebno je izražen problem iznalaženja modela saradnje koji će na adekvatan način razrešiti sukob načela solidarnosti i konkurencije među članicama Evropske unije.

Ključno pitanje u oceni buduće pozicije EU jeste da li će ona razviti dovoljnu političku i socio-kulturnu koheziju da deluje kao jedna jedinica na velikom broju međunarodnih pitanja, ili će ostati ograničena grupa država sa snažnim različitim nacionalizmima i spoljnim politikama. Ujedinjena Evropa bio je spor, ali stalan proces tokom pola veka, a pritisci globalizacije doprineli su podsticajima za jačanje evropskih regionalnih institucija. Međutim, Evropa se suočava sa značajnim ograničenjima u stepenu jedinstva. Nacionalni identiteti ostaju snažniji od zajedničkog evropskog identiteta, uprkos pedesetogodišnjoj integraciji, a nacionalni interesi, iako manji u poređenju sa prošlošću, još uvek su bitni. Integracija spoljne i odbrambene politike posebno je sporna. Evropska unija je 1999. godine stvorila mogućnost za zvaničnike na visokom nivou da koordiniraju spoljne politike i postigla saglasnost o stvaranju vojske od 60.000 vojnika za intervencije u slučaju krize, podržane neophodnim komandnim osobljem, obaveštajnim organima i donosiocima odluka. Druge evropske zemlje želele su da budu sigurne da nove snage neće ni na koji način oslabiti NATO i američko angažovanje u Evropi. Ideja o umerenoj evropskoj vojsci koja bi bila „odvojiva, ali ne i odvojena” od NATO-a mogla bi u suštini da ojača alijansu omogućavajući bolju podelu tereta preko unapređenih evropskih kapaciteta koji bi se bavili minornim unutarevropskim konfliktima.

Početkom 2009. godine gasni spor Rusije i Ukrajine, praćen obustavom značajnog dela isporuka ruskog gasa za Evropu, uključujući i Srbiju, dodatno je aktuelizovao pitanje energetskih odnosa Evropske unije i Rusije. Rusija je najveći svetski proizvođač gasa. Sa druge strane, EU je najveće svetsko tržište gasa. Istovremeno, oni su susedi. Logično je da bi EU i Rusija trebalo da imaju dobro razvijene energetske odnose. Evropska unija dobija oko 40 posto potrebnog gasa uvozom iz Rusije, a dve trećine ruskog izvoza gasa

\footnotetext{
${ }^{36}$ D. Simić, , Nauka o bezbednosti”, Beograd, 2002, str. 68.
} 
ide u države Unije. Iz Rusije, takođe, dolazi skoro trećina nafte potrebne Uniji i četvrtina njenog uvoza uglja. Evropske kompanije su među najvećim investitorima u ruskim sektorima nafte, gasa i električne energije. $U$ isto vreme, ruski energetski giganti teže većem pristupu tržištu Unije, kako bi sakupili kapital i kupili elektrane i gasovode. Energetski odnosi Unije i Rusije trebalo bi da budu direktni, međusobno korisni i u fazi brzog razvoja. Ali, oni to nisu. Mnogi Evropljani danas doživljavaju kao pretnju njihovu zavisnost od ruskih energenata, pogotovo gasa. Pojedinci smatraju da Rusija koristi energiju kao političko oružje i da joj se, kao snabdevaču, ne može verovati. Drugi manje brinu o ruskoj spremnosti da izvozi energiju, a više o njenoj sposobnosti da to postigne. Uprkos rekordno visokim globalnim cenama, ruska proizvodnja nafte i gasa stagnira, pošto ruske kompanije ne investiraju dovoljno u istraživanje novih polja. $U$ isto vreme, oni govore o prodaji većih količina gasa u Aziji i o ulasku na globalno tržište LNG (tečni prirodni gas). Zbog toga Unija pojačava napore da pronađe alternativne izvore snabdevanja, kako geografski (uglavnom iz Severne Afrike i iz Kaspijskog regiona), tako i kroz razvoj obnovljivih izvora, čistog uglja u pojedinim državama i nuklearne energije. Sa ruske tačke gledišta, evropska debata nema smisla. Evropljani stalno zahtevaju od Rusije da troši ogromne količine novca za razradu novih polja, ali odbijaju da Rusiji predoče jasnu ideju o tome koliko će gasa želeti da kupuje od nje, recimo, za 20 godina. Ima se utisak da žele da Rusija dozvoli zapadnim energetskim kompanijama da više investiraju u ruski energetski sektor. Istovremeno, pišu nova pravila kako bi sprečili ruske kompanije da kupuju gasovode i naftovode u Uniji. Uprkos plemenitim rečima o „energetskoj solidarnosti EU”, kompanije iz pojedinačnih članica EU su srećne što potpisuju dugoročne ugovore o snabdevanju sa Rusijom. Neke od ovih kompanija su se ujedinile sa ruskim gigantima u izgradnji novih podmorskih gasovoda koje druge članice Unije doživljavaju kao pretnju njihovoj energetskoj bezbednosti. Zato se Rusiji upućuju optužbe za strategiju „zavadi pa vladaj”. Naravno, energetske veze EU i Rusije ne žive u političkom vakuumu. One su integralni deo političkih, ekonomskih i bezbednosnih odnosa koji postaju sve kompleksniji i teži. Tenzije u odnosima su već nekoliko godina u porastu. Evropljani se bore da pronađu pravac kako da sarađuju sa Rusijom koja ograničava demokratiju kod kuće, pritiska svoje susede i opstruiše međunarodne inicijative. Sa sve više samopouzdanja i opskrbljena gotovim novcem, Rusija, s druge strane, nije raspoložena da dobija lekcije od Unije koju smatra slabom i arogantnom. Rat u Gruziji, avgusta 2008, samo je pogoršao situaciju. Evropljani prihvataju da treba da preduzmu veću odgovornost u stabilizaciji svog istočnog susedstva. Međutim, u isto vreme, oni se osećaju nemoćnim, suočeni sa nastojanjima Rusije da u istoj oblasti konsoliduje i proširi svoj uticaj.

\section{Zaključak}

Moglo bi se zaključiti da danas u svetu postoje tri geografske koncentracije između kojih se, uglavnom, kreću svetska trgovina i investicije. To su: Zapadna Evropa, Severna Amerika i Japan sa Jugoistočnom Azijom. Ova područja, prema brojnim kriterijumima, pripadaju jezgru svetskog sistema. Motivacija za regionalnu ekonomsku saradnju i slobodnu trgovinu bila je, kao i u slučaju EU, severnoameričko područje slobodne trgovine (NAFTA - North American Free Trade Area) i ASEAN, nadmetanje sa drugim područ- 
jem. Po Haushoferu (Haushofer) „(trgovački) blokovi sami po sebi, dovoljno su velika tržišta da ako to odaberu mogu da stanu nasuprot globalnom principu". Zbog toga je najverovatniji ishod sadašnje situacije da će budući sistem karakterisati nadmetanje tih pan područja. Ono oko čega će se područja nadmetati mogu bili liderstvo, investicije, sirovine, energije, tržišta, patenti i drugo. Sfera interesa tri bloka presecale bi se na Srednjem istoku i u južnoj Aziji. Naftni izvori u području Zaliva, koji čini $60 \%$ do sada poznatih svetskih rezervi, bili bi značajni za sve njih. Evropa bi imala izvesnu geografsku prednost i stabilnost. Srednji istok se ističe kao jedan od najznačajnijih ciljeva u strategiji SAD. Pored Japana, postoje i druge zemlje u istočnoj Aziji, uključujući i Kinu, koje postaju sve zavisnije od uvozne nafte. Distribucija moći u ovom scenariju je ravnomernija nego u svetu jedne supersile. Prisustvo geopolitike je očiglednije, ekonomska konkurencija oštrija i kontrola prostora i veličine uticaja značajnija. Veze između Severne Amerike i Evrope bi oslabile, a NATO bi mogao da se od vojne alijanse transformiše u organizaciju za održavanje mira pod pokroviteljstvom UN i Organizacije za bezbednost i saradnju u Evropi. Zapadnoevropska unija postala bi organizacija EU, odvojena od NATO-a, a EU bi težila da ostvari globalan politički, vojni i ekonomski uticaj. To bi, s druge strane, značilo da bi zadaci na jačanju Zapadnoevropske unije takođe postali globalni. Bez američke zaštite EU bi bila prinuđena da, zbog političkih i bezbednosnih razloga, sarađuje sa Rusijom, čak i tešnje nego što sada čini. Rusija se ne protivi tako žestokom proširivanju EU kao proširivanju NATO-a, pa bi saradnja između ujedinjene zapadne Evrope i Rusije, kao eventualni ishod toga, bila u skladu sa starim teorijama o pan područjima. Ako bi ovaj pristup uspeo, opasnost od konfrontacija u severnoj Evropi bi se smanjila i EU bi mogla da se usredsredi na obezbeđivanje svojih interesa u drugim delovima sveta. Jedan od preduslova za miran kooperativni pristup jeste da privreda Rusije treba da profitira iz jedne takve situacije. Takav kooperativni aranžman mogao bi, takođe, da bude atraktivan za Rusiju, pošto bi mirna granica na zapadu oslobodila njene resurse za južni i istočni front gde, inače, postoji pritisak.

Jedan od prethodno prezentovanih geostrategijskih pregrupisavanja bio je podela sveta na dva rivalska bloka. Tendencija u pravcu APEC-a mogla bi konačno da dovede svet u situaciju u kojoj severni Atlantik nije više ujedinjujući „središnji okean” već prostor koji razdvaja dve ogromne koalicije: Evropu sa njenim saveznicima i američkoazijsku koaliciju. Čak i ako nije reč o igri čiji je sumarni skor nula, Evropa bi bila izostavljena iz saradnje u okviru APEC-a, koja bi uključivala zemlje sa najbržim privrednim rastom u svetu. Interesi Rusije u Evropi i Aziji toliko bi postali različiti da bi ova zemlja mogla da pokuša da balansira između dva bloka ili bi se mogla čak rastaviti na dva ili više delova. Konkurencija EU bila bi mnogo oštrija nego u prethodnom slučaju, posebno na srednjem istoku, ako se imaju u vidu resursi koalicije APEC-a. Takođe, i „zajednički interesi” mogu lako da potisnu jednako vredne „privatne interese” pojedinih naroda ili subregiona. Što je veći entitet, to su i krupnija pitanja koja se mogu otpisati kao „individualna” i zapostaviti. U scenariju velikih sila država bi, takođe, imala suštinsku ulogu u oblasti bezbednosne politike. Opšta odgovornost za globalnu i regionalnu bezbednost bila bi na međunarodnim organizacijama, kao što su UN i OEBS, koje nisu diskriminatorske. Globalno nadmetanje između velikih sila moglo je da opredeli Rusiju da pojača svoje aspiracije i ponovo uspostavi svoju staru imperiju, obezbeđujući, možda, azijski front, savezom sa Kinom. 


\section{Literatura}

[1] Naj Dž.: Paradoks američke moći, BMG, Beograd, 2004.

[2] Sojanović, S i Nikolić, S.: „Nova globalna podela moći”, Beograd, 2009.

[3] Danner M.: „Marooned in the Cold War”, World Policy Journal, XIV 3, 1997

[4] Mandelbraun, M.: Ideje koje su osvojile svet, Filip Višnjić, Beograd, 2004.

[5] Ivanović, Ž.: „Put u carstvo dobra vodi u apokalipsu”, u: Zbornik Ka carstvu dobra ili apokalipsa, (priredio Ž. Ivanović) Beograd, 2003.

[6] Politika, 10. maj 2006.

[7] SIPRI Yearbook 2006 Armaments, Disarmament and International Security, http.// www.sipri.org.

[8] SIPRI Yearbook 2006 Armaments, Disarmament and International Security, http./l www.sipri.org

[9] The Military Balance 2005-2006

[10] Nikoliš, D.: „O globalizaciji kao političkom (i geopolitičkom i vojnobezbednosnom) fenomenu međunarodnih odnosa i Sjedinjenih Država u njima", u: Vreme globalizacije

[11] Kler, M. T.: Krv i nafta, Znanje, Zagreb, 2005.

[12] Kremer U.: „Novi NATO - novi ratovi”, Filip Višnjić, Beograd, 2000.

[13] Gligorijević, S.: „Evropska bezbednosna i odbrambena politika”, Seminar o Evropskoj bezbednosnoj i odbrambenoj politici, Ministarstvo odbrane Republike Srbije, decembar 2006.

[14] Simić. D.: Nauka o bezbednosti, Beograd, 2002.

[15] http://siadapp.dmdc.osd.mil/personnel/MILITARY/ms0.pd

[16] http://money.cnn.com/magazines/fortune/global500/2007/countries/US.html

[17] http://money.cnn.com/magazines/fortune/global500/2007/countries/US.html 